\title{
Introducing the Role of Gender Through the Role Playing Method in Children 4-5 Years Old at RA Al Hub, Jakarta Selatan
}

\author{
Dwi Puji Lestari ${ }^{1}$, Saihu ${ }^{2}$, and Humaidi ${ }^{3}$ \\ \{pldwi1022@gmail.com¹, madesaihu@ptiq.ac.id ${ }^{2}$, humaidias97@gmail.com³ \\ ${ }^{1}$ STAI Al Aqidah Al Hasyimiyyah, Jakarta, Indonesia \\ ${ }^{2}$ PTIQ Jakarta, Indonesia \\ ${ }^{3}$ STFI Sadra, Indonesia
}

\begin{abstract}
This research aim to improve understanding of gender roles through the role playing method in RA B Az Zahra Kebayoran Baru, South Jakarta. This research was conducted in children group A 4-5 years, amounting to 20 children. This research is an action research with Kemmis and Taggart models consisting of 4 stages, namely (plan, action, observation and reflection). This study consisted of 2 cycles. Data collection techniques are using observation, field notes, and documentation. Data analysis uses quantitative and qualitative. The results showed that there was an increase in understanding the role of sex through the role playing method with the results of research showed that the pre-cycle achieved an average score of 9.73 which is in the category yet Evolving, while the second cycle has average 32, 02 are in the category of Emerging Very Good, while in the second cycle has an average cycle as much as 35.02 is in the category is growing very well.
\end{abstract}

Keywords: Gender Roles, Role Playing Methods and Action Research

\section{Introduction}

Biologically between men and women are different. Differences in the characteristics of women and men saw since childhood where the tad more of a chance to play outside the house and they played longer than females, game boys are more competitive and constructive for boys more diligently and more effectively than girls, and more girls games and more cooperative in the room. Biological and psychological differences have resulted in the opinions that harm women. So we need to introduce the role of sex to children from an early age.

Introduce the role of gender in children from an early age is important because in age the golden of intelligence has increased to 80 percent. The formation of self-concept in children will affect the formation of personality and behavior as an adult. The introduction of differences in gender roles to be done exactly, because it will be stored in the long-term memory of children.

According to the results observed in RA Al Hub Kebayoran Baru, South Jakarta at the time of arrival Group A has students of 15 people. Consisting of 9 boys and 6 girls. When asked children should not wear lipstick male around 6 or $40 \%$ boys allowed. When asked should not boys wear gold rings there are three or $20 \%$ boys should answer. When girls were asked make up girls may not like men, there are 6 or $40 \%$ of girls answered allowed. 
Education is the key to the realization of gender roles according to their biological state. Elizabeth Hurlock said that one of the tasks developments in late childhood children should learn to play the role of sex-approved social groups, learn to play the sex is approved for personal and social adjustment better because of failure to master the role sex will bring social reaction adverse later will affect the child's self-concept [1]. To succeed in learning the role of gender as a teacher should encourage children to play and get into their world. One method that can be used is a method of playing a role because through this method the child will portray ordinary things done every day born in the child without any engineering so that what they play is inherent in the child.

\section{Role of Gender}

Hungu 2007 according to gender (sex) is the difference between women and men are biological since the person was born. Sex-related to the male body and the female, where men produce sperm, while women produce eggs and are biologically able to menstruation, pregnancy, and lactation. Biological differences and the biological functions of men and women are not interchangeable between them, and the functions should remain with the men and women of all races that exist on earth [2]. According to the Bee [3], the difference in behavior based on gender began to appear as early as age 4 or approaching the age of 5 years. There is a striking difference in the behavior of children against harmful peer based on gender. Girls prefer to use the expression of displeasure to other children, Other behavior, when a girl is not happy with the other girls, is to show the face of gloomy and silent [4]

According to Bacon and Learner in terms of activity, girls at this age is to build a feeling that there are certain activities that are only suitable for boys and girls [5], According to Manes and Melnyk on the other component, which is related to the ideas or expectations. Girls tend to have lower job orientation than men. It is also highly dependent how the influence of social and cultural climate of family, school, especially giving presumption against the child, as well as prevailing gender stereotypes in the communities where these children live. Girls who aspire lower than boys giving [6].

From the exposure of gender roles can be concluded that the device behavior that is expected of people who showed differences between women and men biologically determines the difference of their role in organizing efforts to continue the lineage that includes behaviors, activities, ideals and critical nature.

\section{Role Playing}

Mulyono say Roleplaying (role playing), which is a way of mastering learning materials through the development of imagination and appreciation of students. Method of playing a role or role-playing is a learning process belonging to the simulation method [7]. Djamarah says that the method of role-playing (play a role) can also be interpreted in a way the mastery of materials through the development and appreciation of the students. Development of imagination and appreciation made by students with play her as a character living or inanimate. With this play, activity will make students more permeates acquisition. Some things to consider in the implementation of the method of playing this role is the determination of the topic, the determination of the cast members, creation worksheet (if necessary), a short exercise dialog (if necessary) and implementation of role-plays [8].

Joyce, Weil, and Calhoun, which suggests that playing a role is a model that is versatile and can be used to try to achieve some important educational goals. At a simple level to play 
the role of dealing with the problem through action, described the problem, take action and discussed [9]. Most of the students as a player and partly as an observer. Students will experience how to be in the position of the player and the observer all this because there is a charge for the interaction of empathy, sympathy and anger and compassion in the sense of emotional involve them. According to Uno (2014: 2014) playing the role of a learning, the model aims to help students discover the meaning of self (identity) in the social world and solve the dilemma with the help of the group.

\section{Research Methods}

Methods in this study are action research using a model Kemmis and Taggart. Which consists of four components, namely : planning(planning), action(acting), observation(observing)and reflection(reflecting). Data collection techniques in this study are the use of (a) observation monitors actions in children and teachers (b) Interview and (c) documentation. Type of instrument used is the use of nontest in the form of shaped pieces of observation monitoring of action.

Data analysis performed in this study is in two ways quantitative descriptive analysis techniques and qualitative data. Descriptive statistics to compare the results obtained from the first cycle and the second cycle in the form of the average number of arithmetic (mean) and calculation/measurement of the percentage form. Qualitative data analysis conducted on data collected through interviews, field notes researcher, and reflection.

\section{Result and Discussion}

Based on the analysis carried out has been done, there is a performance enhancement capability development of gender roles children 4-5 years old kindergarten Al Hub, South Jakarta. In the pre-cycle achieved an average score of 9.73 which is in the category yet Evolving, while the second cycle has average 32, 02 are in the category of Emerging Very Good, while in the second cycle has an average cycle as much as 35.02 is in the category is growing very well From the observation of pre-cycle there are some indicators such as 1) Indicators make corrections in the form of verbal or act against oneself about the state of nonconformity with gender, 2) Indicators of child capable behave according to the rules that bind sexes usually declines with the development of the child's age, 3 ) Indicators capable activity children according to gender, 4) Indicators capable of aspiring child according to gender. Each of these indicators increased in each cycle. Here's the explanation.

On indicators make corrections in the form of oral or act against oneself about the state of nonconformity with gender in the pre-cycle has an average score of 6.73 in the undeveloped category, the first cycle an average score of 29, 13 in the category of developing appropriate expectations, the second cycle an average score of 35.33 in the category is growing very well. On the child is able behave indicator according to the rules binding the sexes usually declines with age development of children at pre-cycle has an average score of 9, 07 in the category of undeveloped, the first cycle an average score of 28.53 in the category of developing according to expectations (BSH), the second cycle an average score of 36, 13 in the category is growing very well. In the child is able to activity appropriate indicators by gender, at pre-cycle has an average score of 9, 07 in the category of undeveloped (BB), the first cycle an average score of 30.00 in the category of developing according to expectations, cycle II score average 35.73 in the category is growing very well 
On indicator capable of the aspiring child according to gender. In the pre-cycle has an average score of 9, 53 in the category of undeveloped, the first cycle an average score of 20.40 in the category of developing according to expectations the second cycle an average score of 35.40 in the category is growing very good.

In the context of education, according to Purwanti education provide equal opportunities to each gender. Treatment and equal opportunity in education to the sexes, giving subjects according to their talents and interests of each individual, dan individual in education is also directed to get quality according to their ability and interest level. In the context of sex education, all have an equal opportunity to education [10].

\section{Conclussions}

Based on the findings of this study, it can be concluded that an increase in the role of gender through role-playing. Results of research addressing the increase of pre-cycle achieved an average score of 9.73 which is in the category yet Evolving, while the second cycle has average 32, 02 are in the category of Emerging Very Good, while in the second cycle has an average cycle as much as 35.02 is in the category is growing very well.

\section{References}

[1] Elizabeth B.Hurlock, Perkembangan Anak. Jakarta: Erlangga, 2002.

[2] Tina Peterson, "Professionalism of preschool teachers in Estonia, Finland, Sweden and Hungary," Eur. Early Child. Educ. Res. Journal, vol. 24, no. 1, pp. 136-156, 2016.

[3] H. Bee, The Developing Child. New York: HarperCollins College Publishers, 2002.

[4] Christine Macintyre, Understanding Children's Development In The Early Years. London: Routledge, 2007.

[5] and R. . L. Bacon, C., "Effects of Maternal Employment status on the Development of Vocational Role Perception in Females," Genet. Psychol., vol. 126, pp. 187-193.

[6] Manes AL and P Melnyk, "Televised Models of Female Achievment," Telev. Model. Female Achievment, vol. 4, pp. 365-374, 1974.

[7] Mulyono, Strategi Pembelajaran. Malang: UIN Maliki Press, 2012.

[8] Syaiful Bahri Djamarah, Guru Dan Anak Didik Dalam Interaksi Edukatif. Jakarta: PT Rineka Cipta, 2005.

[9] M. W. dan E. C. Bruce Joyce, Model Of Teaching. Yogyakarta: Pustaka Pelajar, 2016.

[10] Eni Purwati dan Hanun Asrohah, Bias Gender dalam Pendidikan Islam. Surabaya: Alpha, 2005. 